\title{
Somatostatin Coordinately Regulates Glucagon Gene Expression and Exocytosis in HIT-T15 Cells
}

\author{
David M. Kendall, * Vincent Poitout, * L. Karl Olson, * Robert L. Sorenson, ${ }^{\star}$ and R. Paul Robertson* \\ *Division of Diabetes, Endocrinology, and Metabolism, Department of Medicine, and ${ }^{\ddagger}$ Department of Cell Biology and Neuroanatomy, \\ University of Minnesota Medical School, Minneapolis, Minnesota 55455
}

\begin{abstract}
Somatostatin (SRIF) regulates secretion from several endocrine cell types. SRIF inhibits both insulin and glucagon secretion and reduces insulin gene expression. However, whether SRIF inhibition of glucagon secretion from the pancreatic alpha cell is mediated via pertussis toxin-sensitive G-proteins is not presently known, nor has it been determined whether SRIF can regulate glucagon gene expression. Consequently, we performed studies in the transformed islet cell line HIT-T15 to determine whether the inhibitory effect of SRIF on glucagon exocytosis is preserved in this cell line, whether this effect is mediated through a pertussis toxinsensitive mechanism, and whether SRIF has an inhibitory effect on glucagon gene expression. Confocal microscopy with immunostaining revealed that $15-25 \%$ of HIT-T15 cells contained glucagon. In static incubations forskolin (FSK, $1 \mu \mathrm{M})$ increased glucagon secretion 3.6 \pm 0.9 -fold $(P$ $<0.01$ ) and mixed amino acids $(15 \mathrm{mM})$ increased glucagon secretion $2.8 \pm 0.4$-fold $(P<0.01)$. Addition of SRIF significantly inhibited both forskolin- and amino acid-stimulated secretion. Maximal inhibition of both FSK- and amino acidstimulated secretion occurred at SRIF concentrations $\geq 10^{-8} \mathrm{M}$ and these inhibitory effects were completely prevented by pertussis toxin pretreatment. In addition to inhibiting glucagon secretion, SRIF significantly reduced both basal and FSK-stimulated glucagon mRNA levels and this reduction in glucagon mRNA was completely prevented by the addition of cyclic AMP analogue. Glucagon gene promoter activity, as assessed by transient transfection experiments, was stimulated $2.1 \pm 0.25$-fold by forskolin $(P$ $<0.01)$. This effect was significantly inhibited by SRIF (71 $\pm 4 \%$ reduction from FSK alone, $P<0.04$ ) suggesting that SRIF inhibition of the glucagon promoter may, at least in part, aecount for the observed decrease in glucagon mRNA levels. These studies uniquely demonstrate that glucagon secretion from the HIT-T15 cell line is inhibited by SRIF through a pertussis toxin-sensitive mechanism and
\end{abstract}

Address correspondence to David M. Kendall, M.D., Box 101 UMHC, Division of Diabetes, Endocrinology, and Metabolism, University of Minnesota, Minneapolis, MN 55455. Phone: 612-626-1960; FAX: $612-$ 626-3133; E-mail: kendall@lenti.med.umn.edu

Received for publication 5 May 1995 and accepted in revised form 11 August 1995.

J. Clin. Invest.

(C) The American Society for Clinical Investigation, Inc. 0021-9738/95/11/2496/07 \$2.00

Volume 96, November 1995, 2496-2502 that SRIF also inhibits glucagon gene expression in part by reducing glucagon promoter activity. These findings indicate that SRIF can coordinately regulate glucagon delivery by the alpha cell both at the level of gene expression and hormone exocytosis. (J. Clin. Invest. 1995. 96:2496-2502.) Key words: alpha cell $\cdot$ glucagon gene transcription - somatostatin

\section{Introduction}

Somatostatin (SRIF) ${ }^{1}$ inhibits hormone secretion from a number of endocrine cell types. In some cells, including the pancreatic $\beta$ cell, this process is known to occur via specific pertussis toxin-sensitive guanine nucleotide binding proteins (G-proteins ) (1). Within the pancreatic islet, SRIF inhibits both glucagon and insulin release. However, it has not been established whether SRIF inhibition of glucagon secretion from the pancreatic alpha cell is dependent on pertussis toxin-sensitive Gproteins. In addition, the effects of SRIF on the pancreatic alpha cell have been generally assumed to occur only at the level of hormone exocytosis. However, we have previously reported that SRIF decreases levels of insulin mRNA and reduces insulin gene promoter activity $(2,3)$. This raises the possibility that SRIF might also regulate glucagon gene expression, a notion supported by data from others indicating that islet hormone products such as insulin and glucagon can regulate glucagon gene expression. For example, Philippe demonstrated that insulin inhibits both glucagon release and glucagon gene transcription in a hamster islet cell line (4) and Drucker, using a transgenic mouse model, demonstrated that circulating glucagon can inhibit expression of its own gene (5).

The HIT-T15 cell is an SV-40-transformed hamster islet cell line that synthesizes and secretes predominantly insulin (6). These cells have been widely used in studies of regulated insulin secretion (7). However, this cell line also exhibits regulated glucagon secretion (8) and gene expression (9) and has been used successfully in studies of both insulin $(3,10)$ and glucagon gene promoter activity (9).

These studies were performed $(a)$ to more completely characterize glucagon content and secretion from HIT-T15 cells; (b) to determine whether SRIF inhibition of glucagon secretion in these cells is dependent on pertussis toxin-sensitive substrates; and (c) to ascertain whether SRIF may have previously unrecognized regulatory effects on glucagon gene expression.

1. Abbreviations used in this paper: CAT, chloramphenicol acetyltransferase; FSK, forskolin; RSV, Rous sarcoma virus; SRIF, somatostatin. 


\section{Methods}

Cell culture. HIT-T15 cells were grown in $5 \% \mathrm{CO}_{2} / 95 \%$ air at $37^{\circ} \mathrm{C}$ and maintained in RPMI-1640 culture media containing $11.1 \mathrm{mM}$ glucose and $10 \%$ fetal bovine serum. Media were changed every 2-3 d and cells were passed weekly after trypsin-EDTA detachment. Studies were performed using passages 73-90.

Glucagon content, immunohistochemistry, and confocal microscopy. Glucagon content was determined using $1 \times 10^{6}$ cells subcultured for $48 \mathrm{~h}$ in 12-well culture plates. Samples were prepared by acid ethanol extraction (6) and assayed for glucagon content by radioimmunoassay using antibody 04 as described previously (11). Immunohistochemistry and confocal microscopy were performed on HIT-T15 cells (passages 75 and 93) grown on coverslips in 12-well plates in RPMI-1640 culture media containing $10 \%$ fetal bovine serum, penicillin, streptomycin, and amphotericin B. During log-phase growth, the cells were fixed with 4\% paraformaldehyde for $30 \mathrm{~min}$ at room temperature. The cells were then thoroughly washed with PBS before applying the primary antiserum diluted in PBS/0.3\% Triton (mouse monoclonal antiinsulin [NovoBiolabs, Bagsvœrd, Denmark] at 1:100, rabbit antiglucagon at 1:200, and rabbit anti-SRIF at 1:200). Cells were incubated in the presence of the primary antibody overnight at $4^{\circ} \mathrm{C}$. For the single labeling experiments, the second antibodies were cyanine 3.18-labeled donkey anti-rabbit or cyanine 3.18-labeled donkey anti-guinea pig serum diluted to 1:500 with PBS. The cells were then washed six times with PBS before mounting in no-fade medium and fixation onto glass slides. For the doublelabeling experiments, the procedures were similar except that the cells were treated with successive applications of the primary antibodies. The secondary antibodies were either cyanine 3.18-labeled donkey antiguinea pig diluted to 1:400 or fluorescein-labeled donkey anti-rabbit diluted to 1:150 in PBS (Jackson ImmunoResearch, West Grove, PA) The immunostained specimens were examined with a confocal microscope (MRC-600) equipped with a krypton/argon laser (both from Bio Rad Corp., Hercules, CA). For the double-labeling experiments, images were pseudo-colored with either red or green using Confocal Assistant software written by T. C. Brelje (Department of Cell Biology and Neuroanatomy, University of Minnesota). In merged images the cells appeared either red, green, or in the case of colocalization, yellow. Final image processing was done using Adobe Photoshop and printed using a Kodak XL 7700 digital printer. Details of these procedures have been reported previously $(12,13)$.

Secretion studies. Glucagon secretion from HIT-T15 cells was assessed in static incubation studies modified from the protocol of Diem et al. (8). After 48-h subculture of $1 \times 10^{6}$ cells/well in 12-well culture plates, media were removed and the cells were stabilized for $30 \mathrm{~min}$ in $\mathrm{KRB}\left(119 \mathrm{mM} \mathrm{NaCl}, 4.74 \mathrm{mM} \mathrm{KCl}, 2.5 \mathrm{mM} \mathrm{CaCl}_{2}, 1.19 \mathrm{mM} \mathrm{MgSO}_{4}\right.$, $1.19 \mathrm{mM} \mathrm{KH}_{2} \mathrm{PO}_{4}, 25 \mathrm{mM} \mathrm{NaHCO}_{3}, 10 \mathrm{mM}$ Hepes, $0.1 \%$ bovine serum albumin, $\mathrm{pH} 7.40)$ containing $11.1 \mathrm{mM}$ glucose. Test buffer $(2.8 \mathrm{mM}$ glucose) with either physiologic mixed amino acids (14) or forskolin (FSK, $1 \mu \mathrm{M}$ ) in the presence or absence of a range of SRIF concentrations was then applied to each well. Cells were incubated at $37^{\circ} \mathrm{C}$ for $60 \mathrm{~min}$. Incubated samples were harvested and glucagon was measured by radioimmunoassay. Aprotinin/EDTA $(100 \mathrm{mU} / \mathrm{ml} / 0.2 \mathrm{mM})$ was added to samples for inhibition of proteolysis. Pertussis toxin studies were performed by preincubating cells for $16 \mathrm{~h}$ with RPMI-1640 containing $20 \mathrm{ng} / \mathrm{ml}$ pertussis toxin before addition of FSK. Mixed amino acids were prepared in KRB from reagent grade stock. FSK was purchased from Sigma Immunochemicals (St. Louis, MO) and SRIF-14 was obtained from Bachem California (Torrance, CA). In static incubation studies and media preparations, $10^{-6} \mathrm{M}$ FSK was used because this concentration has been shown previously to be maximally stimulatory for both insulin secretion and cAMP generation in HIT cells (15). To determine glucagon secretion as a percentage of total content, subcultured cells were prepared as described above, and further cultured for $24 \mathrm{~h}$ in the presence or absence of $10^{-7} \mathrm{M}$ SRIF. Media were reapplied $6 \mathrm{~h}$ before harvest and then collected for glucagon determination. Acidextracted glucagon content of cells was then determined and fractional secretion was calculated as the percentage of total glucagon content.
All static incubation studies were performed on duplicate wells in four to eight separate experiments.

Northern analysis. HIT cells plated at a density of 5-8 $\times 10^{6}$ cells in 60-mm petri dishes were exposed to either RPMI-1640 (11.1 mM glucose), or this same media supplemented with SRIF $\left(10^{-7} \mathrm{M}\right)$, FSK $\left(10^{-6} \mathrm{M}\right)$, or both for $24 \mathrm{~h}$. Test media were reapplied to each plate every 8-12 h. Cells were washed twice with cold PBS and mRNA was isolated according to the procedure of Chomczynski et al. (16). Total RNA $(2-10 \mu \mathrm{g})$ was fractionated on $1.5 \%$ agarose-formaldehyde gels and transferred to nylon hybridization membranes by electroblotting. Prehybridization and hybridization were performed using $50 \%$ formamide; $5 \times$ SSC; $5 \times$ Denhardts; $50 \mathrm{mM}$ sodium phosphate, $\mathrm{pH} 5.85$; $0.1 \mathrm{mg} / \mathrm{ml}$ salmon sperm DNA; and $0.1 \%$ SDS. Membranes were prehybridized at $42^{\circ} \mathrm{C}$ overnight. Rat preproglucagon cDNA probe (gift of D. Drucker, Toronto, Ontario, Canada) oligo-labeled with $\left[{ }^{32} \mathrm{P}\right] \mathrm{d}-\mathrm{CTP}$ was added and membranes were hybridized for an additional $18 \mathrm{~h}$ at $42^{\circ} \mathrm{C}$. Membranes were rinsed three times with $1 \times$ SSC, $0.1 \%$ SDS, and then further washed in $0.1 \times \mathrm{SSC}, 0.1 \%$ SDS at $60^{\circ} \mathrm{C}$ for $90 \mathrm{~min}$. Membranes were exposed to $\mathrm{x}$-ray film for $4-48$-h intervals at $-70^{\circ} \mathrm{C}$ and RNA was quantitated by scanning densitometry of autoradiographs. For purposes of normalization, membranes were stripped at $80^{\circ} \mathrm{C}$ for 1 $h$ in Tris-EDTA buffer ( $1 \mathrm{mM}$ EDTA, $10 \mathrm{mM}$ Tris, $\mathrm{pH} 8$ ) and reprobed with ${ }^{32} \mathrm{P}$-labeled human $\beta$-actin cDNA. The effect of exogenous cAMP on glucagon mRNA level was assessed by the addition of $5 \mathrm{mM} 8-\mathrm{Br}-$ cAMP to media in the presence and absence of SRIF $\left(10^{-7}\right)$. After 24 $h$ of exposure these cells were harvested and RNA extracted as described above. 2.5-5 mg total RNA was applied to slot blot apparatus and membranes were hybridized with glucagon and $\beta$-actin cDNA and quantitated as described above. For statistical comparisons, data from multiple experiments were analyzed and are expressed as relative glucagon mRNA/ $\beta$-actin mRNA.

Glucagon promoter activity. Studies of glucagon promoter activity were performed in HIT-T15 cells using a rat glucagon promoter-chloramphenicol acetyltransferase (CAT) reporter construct (gift of D. Drucker). This plasmid (designated GluCAT) contains a 1.1-kb fragment of the rat glucagon gene 5'-flanking region ligated directly upstream of the CAT coding sequence (17). Transient transfections were performed in cells subcultured in 6-well culture plates at a density of $1.5 \times 10^{6}$ cells/well. After $2-\mathrm{d}$ subculture, cells were washed twice with serum-free RPMI-1640 media and incubated for $4 \mathrm{~h}$ with $1 \mathrm{ml}$ serum-free RPMI- 1640 media containing $1.0 \mu \mathrm{g}$ of GluCAT and $4 \mu \mathrm{g}$ Lipofectin (BRL Technologies, Inc., Gaithersburg, MD). After $4 \mathrm{~h}$ the transfection media were removed by aspiration and $3 \mathrm{ml}$ of either RPMI1640 media or media containing SRIF $\left(10^{-7} \mathrm{M}\right)$, FSK $\left(10^{-6} \mathrm{M}\right)$, or both were applied. $24 \mathrm{~h}$ later $(28 \mathrm{~h}$ after transfection), media were aspirated and cells were washed twice with cold PBS and scraped in 1 $\mathrm{ml} 40 \mathrm{mM}$ Tris, $\mathrm{pH}$ 7.4, $1 \mathrm{mM}$ EDTA, $150 \mathrm{mM} \mathrm{NaCl}$. The cell suspension was pelleted in microfuge tubes, resuspended in $0.25 \mathrm{M}$ Tris, $\mathrm{pH}$ 7.4, and cells were lysed by three freeze-thaw cycles. An aliquot of the supernatant was then assayed for protein by the method of Lowry (18). CAT activity was determined using $15-25 \mu \mathrm{g}$ of total cellular protein

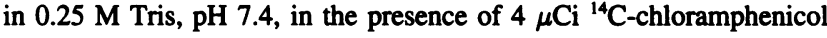
and $0.8 \mathrm{mM}$ acetyl CoA incubated at $37^{\circ} \mathrm{C}$ for $3 \mathrm{~h}$. Acetylated and nonacetylated species of ${ }^{14} \mathrm{C}$-chloramphenicol were extracted in ethyl acetate, separated by TLC on silica gel plates, and visualized by autoradiography. CAT activity was quantified by cutting out appropriate spots on the TLC plate representing acetylated and nonacetylated species of ${ }^{14} \mathrm{C}$-chloramphenicol and counting in a scintillation counter. Each experiment included separate transfection with $0.5 \mu \mathrm{g}$ of the nonspecific Rous sarcoma virus (RSV) promoter-CAT construct ( $\mathrm{pRSVCAT}$ ) incubated under identical experimental conditions, which was used as a control for nonspecific effects on gene transcription. All data are presented as relative GluCAT/RSVCAT activity and are normalized to the control values for each separate experiment.

Statistical analysis. Data are presented as mean \pm SEM. Comparisons between experimental conditions were assessed by Student's $t$ test or appropriate nonparametric tests. Where indicated, values were normalized to control values for each experiment. Level of significance was set at $P<0.05$. 

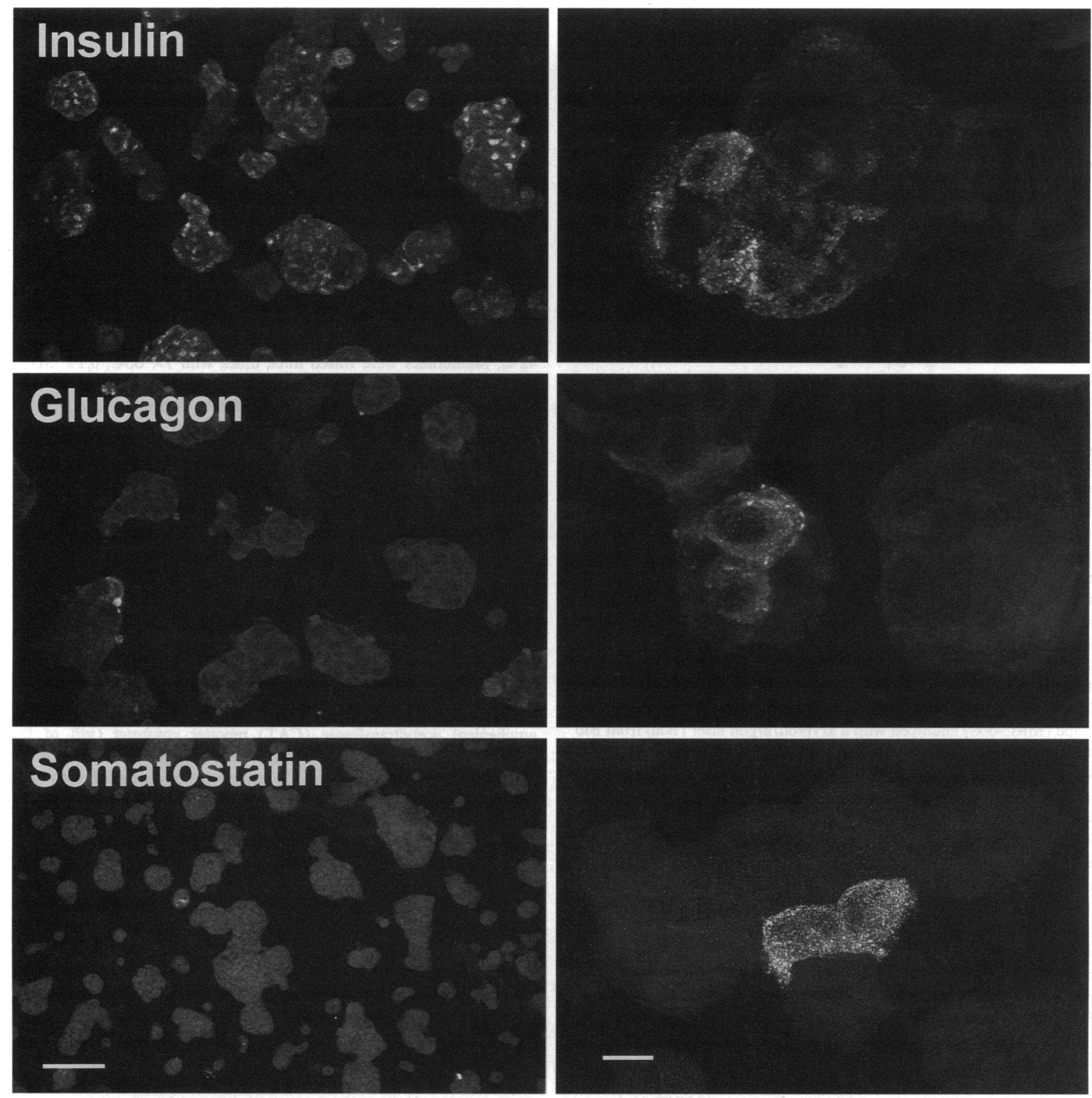

Figure 1. Immunohistochemical localization of insulin, glucagon, and SRIF in HIT-T15 cells (passage 76) by confocal microscopy. Insulin was present in $\sim 50 \%$ of cells. Glucagon was detected in a smaller portion of cells, and SRIF was observed in only a few cells. Bar, left, $50 \mu \mathrm{m} ; r i g h t$, $10 \mu \mathrm{m}$.

\section{Results}

Immunohistochemistry. HIT-T15 cells (passage 76) were examined for the presence of insulin, glucagon, and SRIF (Fig. 1). Insulin was observed in $\sim 55 \%$ of the cells. Among the insulinpositive cells there was a range of staining intensity, suggesting heterogeneity in the amount of insulin contained within these cells. Glucagon was present in $\sim 25 \%$ of the cells. There was little heterogeneity in glucagon-staining intensity, with most of the glucagon-containing cells having a uniform bright appearance. Less than $1 \%$ of cells contained SRIF. To further characterize hormone content, HIT cells were double-stained for insu- lin and glucagon (Fig. 2). By merging the images it was possible to determine whether there was colocalization of more than one hormone within a cell. Most of the HIT cells contained only insulin; however, $10 \%$ of the insulin-containing cells also stained for glucagon. Of the glucagon-containing cells, $\sim 75 \%$ of these contained only glucagon. SRIF did not colocalize with other hormones. These experiments were repeated for HIT cells at later passage (passage 93). In general, the results were similar to those obtained for the younger passage cells. However, the number of insulin-positive cells in the older passage was reduced to $25 \%$ of the total cells. Glucagon was observed in $\sim 15 \%$ of these cells and SRIF in $<1 \%$ of cells. Of the insulin- 

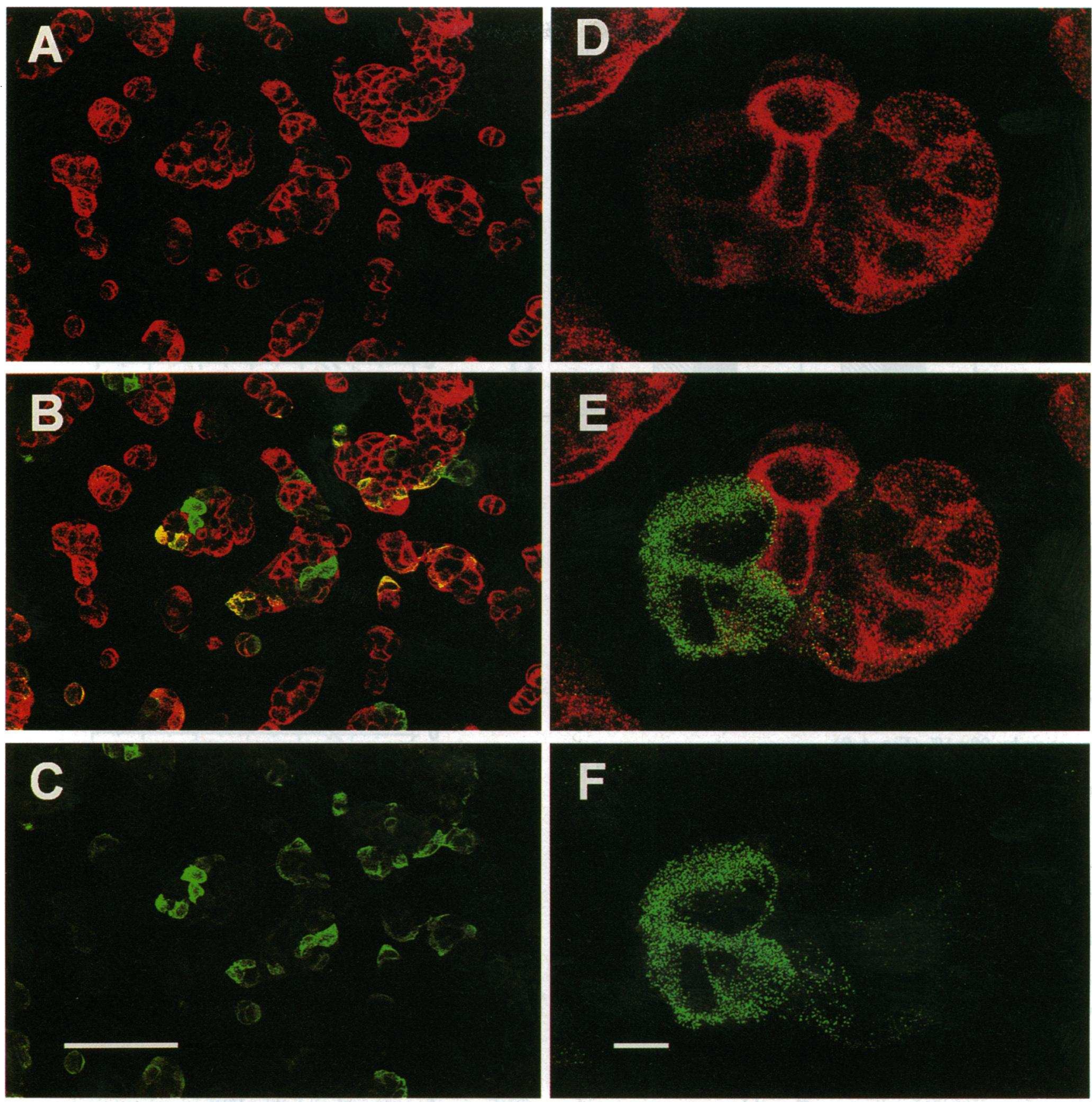

Figure 2. Dual-label immunohistochemistry of insulin and glucagon in HIT-T15 cells. $A$ and $D$ show insulin (red) and $C$ and $F$ show glucagon (green) immunoreactivity. $B$ and $E$ are the merged images of $A$ and $C$, and $D$ and $F$, respectively. Most cells observed contain only insulin. A subpopulation of cells contains both insulin and glucagon (which appear yellow in merged images). However, most glucagon-containing cells contain only glucagon and therefore appear green in merged images. Bar, left, $100 \mu \mathrm{m} ; r i g h t, 10 \mu \mathrm{m}$.

containing cells, $15 \%$ also contained glucagon, and $25 \%$ of the glucagon-containing cells contained insulin. Glucagon content was determined by radioimmunoassay after subculture of $10^{6}$ cells in 12-well plates for $48 \mathrm{~h}$. Mean glucagon content of HITT15 cells was $18,902 \pm 3,079 \mathrm{pg} / \mathrm{ml} / 10^{6}$ cells $(n=8)$. Cells of early (73-80) passage had significantly lower glucagon content compared with those of later $(81-90)$ passage $(13,048 \pm 2,716$ vs. $26,706 \pm 4,736, P<0.02$ ).

Effect of SRIF on stimulated glucagon secretion. Glucagon secretion (picograms per milliliter) from HIT cells was stimulated by both FSK and physiologic mixed amino acids in static incubation experiments and this secretion was significantly inhibited by SRIF $\left(10^{-7} \mathrm{M}\right)$ (Fig. 3). Mixed amino acids stimulated a dose-dependent increase in glucagon release with halfmaximal secretion achieved at an amino acid concentration of $\sim 15 \mathrm{mM}$. At this amino acid concentration, glucagon secretion rose from $679 \pm 213$ to $1,914 \pm 264(P<0.01)$. Similarly, FSK $\left(10^{-6} \mathrm{M}\right)$ stimulated glucagon release from basal levels of $1,106 \pm 161$ to FSK-stimulated levels of $3,981 \pm 985(P<0.01)$. SRIF inhibition of both FSK- and amino acid-stimulated secretion was dose dependent and is shown in Fig. 4. Maximal inhibition of secretion was achieved at SRIF concentrations $\geq 10^{-8}$ 


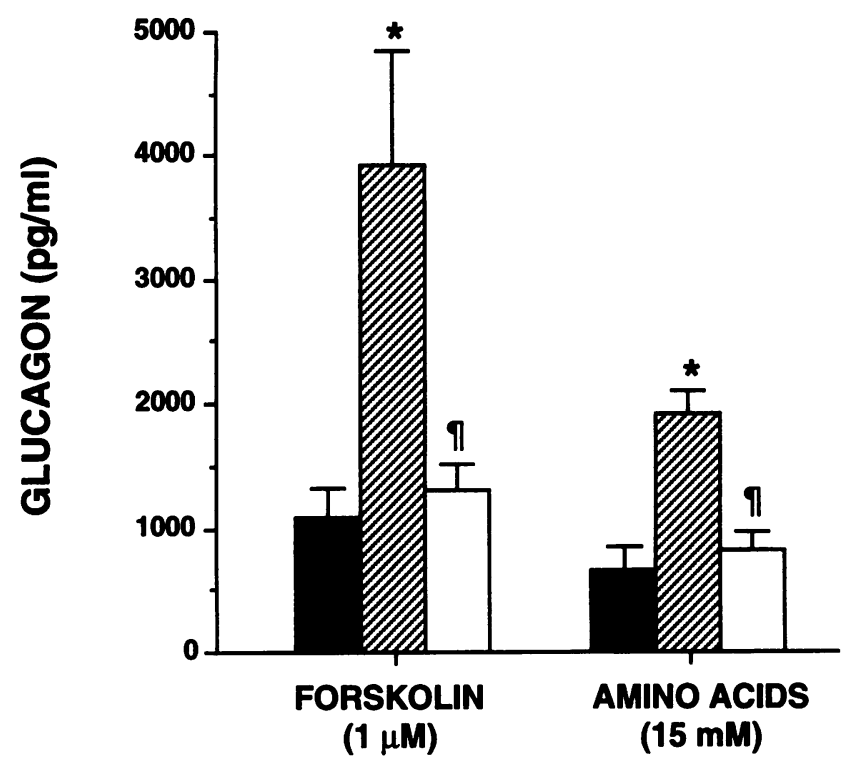

Figure 3. Inhibition of FSK- and amino acid-induced glucagon secretion by SRIF in HIT-T15 cells. Both FSK $(1 \mu \mathrm{M})$ and mixed amino acids stimulate significant increases in glucagon secretion in static incubation. Solid bars, basal; hatched bars, stimulated. This secretion is significantly inhibited by $0.1 \mu \mathrm{M}$ SRIF (open bars, $* P<0.01$ stimulated versus basal, ${ }^{1} P<0.01$ SRIF versus stimulated).

M. SRIF inhibited amino acid-stimulated glucagon secretion by a maximum of $93 \pm 4 \%$ (Fig. $4 A$ ) and inhibited FSK-stimulated secretion by $98 \pm 1 \%$ (Fig. $4 B$ ).

Effect of SRIF on glucagon content. HIT cells cultured in the presence or absence of $10^{-7} \mathrm{M}$ SRIF were assessed for changes in glucagon content $(n=6)$. In these studies, cells cultured under standard conditions (RPMI-1640, $11.1 \mathrm{mM}$ glucose) had glucagon content of $29,468 \pm 4,836 \mathrm{pg} / \mathrm{ml}$. Culture for $24 \mathrm{~h}$ in the presence of SRIF did not significantly reduce glucagon content $(27,573 \pm 6,193, P=0.8)$. Glucagon release into media in these same cells was diminished $68 \%$ by SRIF $(3,957 \pm 539$ [basal] vs. $1,253 \pm 266$ [SRIF], $P<0.01)$, with cells cultured in RPMI secreting $14 \pm 2 \%$ of glucagon content while those cultured in presence of SRIF secreting $6 \pm 2 \%$ of content $(P<0.01)$.

Effect of pertussis toxin pretreatment on SRIF inhibition of glucagon secretion. Neither basal nor FSK-stimulated glucagon release from HIT-T15 cells was affected by pretreatment with pertussis toxin. However, the significant inhibition of FSK-stimulated glucagon secretion in the HIT cell was completely prevented by pertussis toxin pretreatment (Fig. 5).

Effect of SRIF on glucagon mRNA levels. The level of glucagon mRNA in HIT-T15 cells was evaluated by Northern analysis after 24-h culture in either RPMI- 1640 culture media alone or media supplemented with SRIF $\left(10^{-7} \mathrm{M}\right)$, FSK $\left(10^{-6} \mathrm{M}\right)$, or both. A representative audioradiograph of a membrane probed for both glucagon and $\beta$-actin mRNA is shown in Fig. 6. A decrement in basal glucagon mRNA levels was seen in cells cultured with SRIF (lane 2). FSK exposure affected an increase in glucagon mRNA level (lane 3 ) and this increase was also reduced by SRIF (lane 4). Normalized densitometric data from multiple experiments $(n=4)$ are shown graphically in Fig. 7 with data presented as relative glucagon $/ \beta$-actin mRNA. SRIF decreased basal glucagon mRNA levels to $59 \pm 7 \%$ of basal $(P<0.05)$. FSK significantly increased gluca-
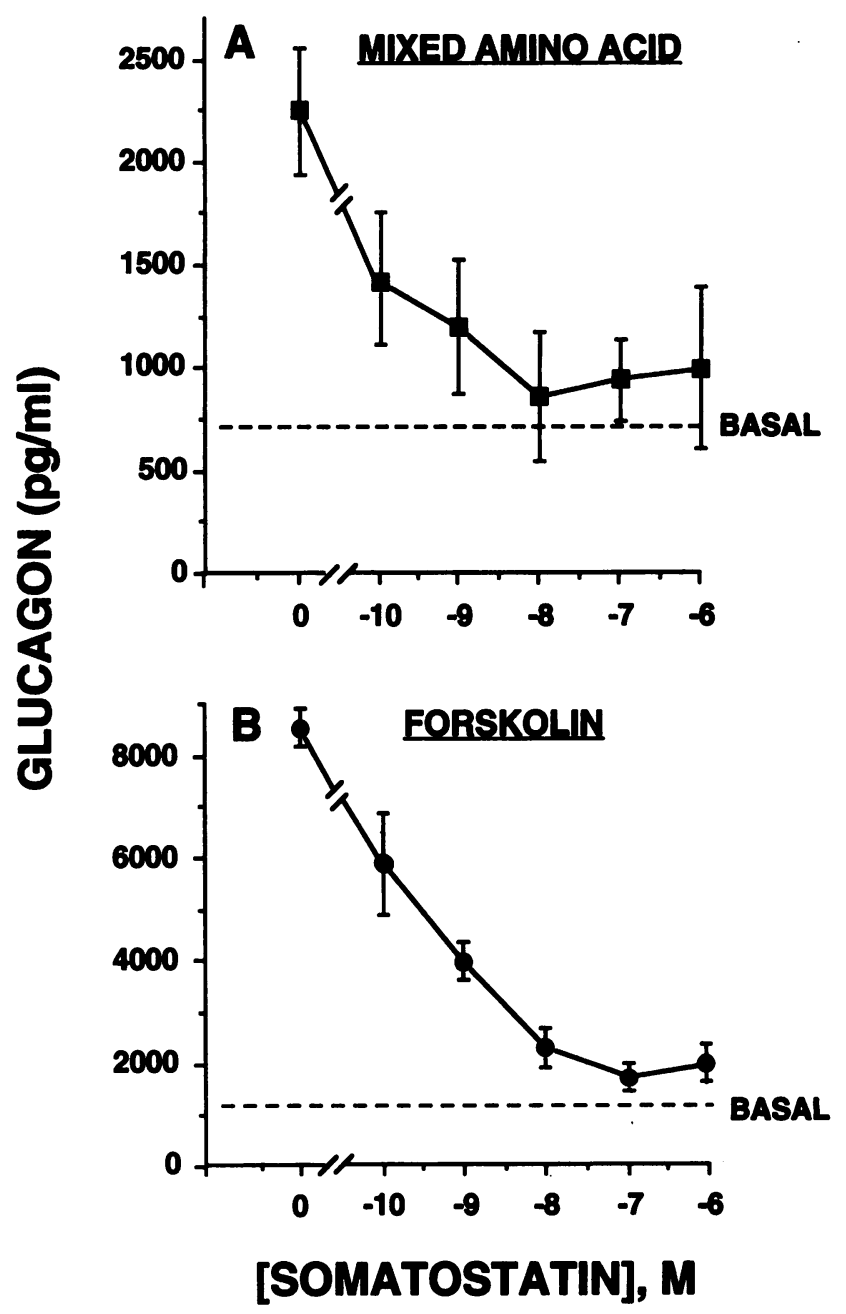

Figure 4. Dose-dependent inhibition of glucagon secretion by SRIF in HIT-T15 cells. SRIF inhibits both amino acid- $(A)$ and FSK-stimulated $(B)$ glucagon secretion from HIT-T15 cells in a dose-dependent fashion. Significant inhibition occurred at all SRIF concentrations $\geq 10^{-10} \mathrm{M}$ with maximal inhibition observed at SRIF concentrations $\geq 10^{-7} \mathrm{M}$. 1-h static incubations were performed on replicate wells as described in Methods.

gon mRNA $(181 \pm 27 \%$ of basal, $P<0.05)$ and addition of SRIF significantly reduced this FSK-stimulated increase in mRNA $(113 \pm 22 \%$ of control, $P<0.04)$.

In the cAMP add-back experiment, HIT cells were exposed to SRIF in the presence or absence of 8-Br-cAMP. SRIF exposure again reduced glucagon mRNA ( $87 \%$ reduction versus basal). Addition of 8 -Br-cAMP caused a 2.6 -fold increase in glucagon mRNA levels and completely prevented the SRIFinduced reduction in glucagon $\mathrm{mRNA}(8-\mathrm{Br}+\mathrm{SRIF}=3.6-$ fold increase over basal).

Effect of SRIF on glucagon promoter activity. Glucagon promoter activity was assessed using the GluCAT promoter construct in transient transfection experiments. CAT activity was determined after 24-h exposure of HIT-T15 cells to either basal culture media or media supplemented with SRIF, FSK, or both (Fig. 8). SRIF alone did not significantly reduce basal promoter activity (control $100 \%$ vs. SRIF $117 \pm 15 \%, P=\mathrm{NS}$ ). However, 24-h exposure to $1 \mu \mathrm{M}$ FSK significantly increased glucagon promoter activity $(211 \pm 28 \%$ of control, $P<0.01)$, 


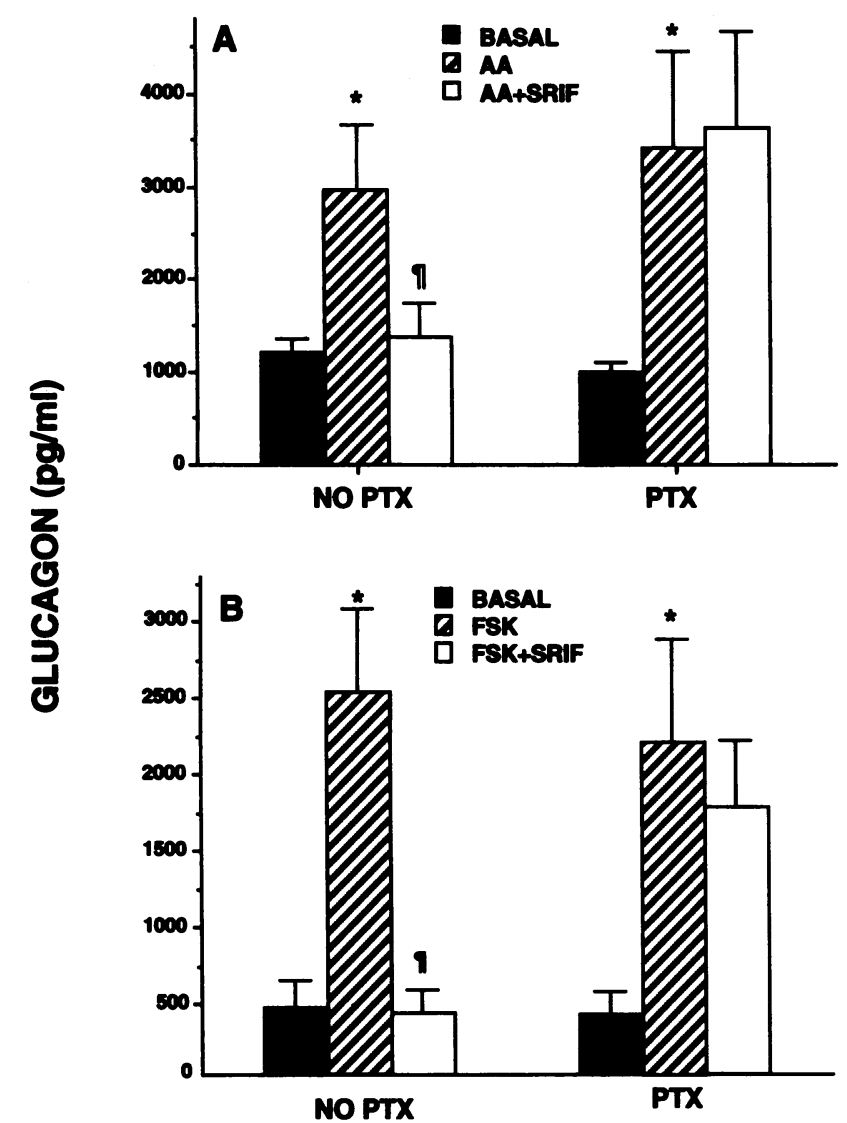

Figure 5. Effect of pertussis toxin (PTX) on SRIF inhibition of glucagon secretion. Pretreatment of HIT-T15 cell with pertussis toxin $(20 \mathrm{ng} / \mathrm{ml})$ completely prevents the inhibitory effects of SRIF on either amino acid$\left(A A\right.$, panel $A$ ) or FSK- (panel $B$ ) stimulated glucagon secretion. ${ }^{*} P$ $<0.01$ basal (solid bar) versus stimulated (hatched bar), ${ }^{\prime} P<0.05$ stimulated versus SRIF (open bar).

and simultaneous incubation with SRIF significantly reduced this FSK-stimulated increase $(148 \pm 13 \%$ of control, $P<0.05)$.

\section{Discussion}

These studies were designed to establish whether SRIF inhibits glucagon secretion from HIT-T15 cells via pertussis toxin-

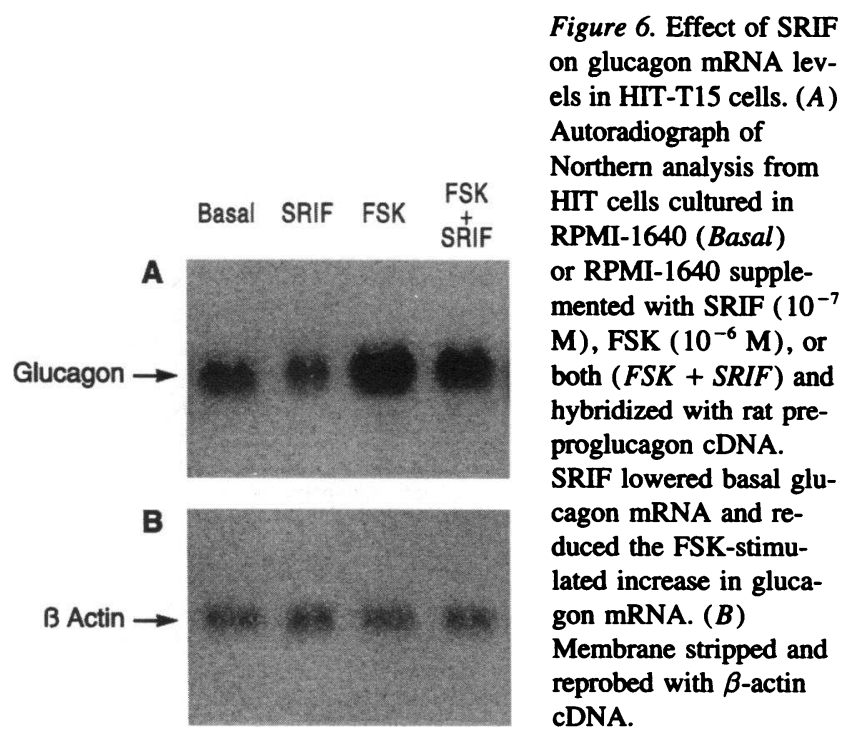

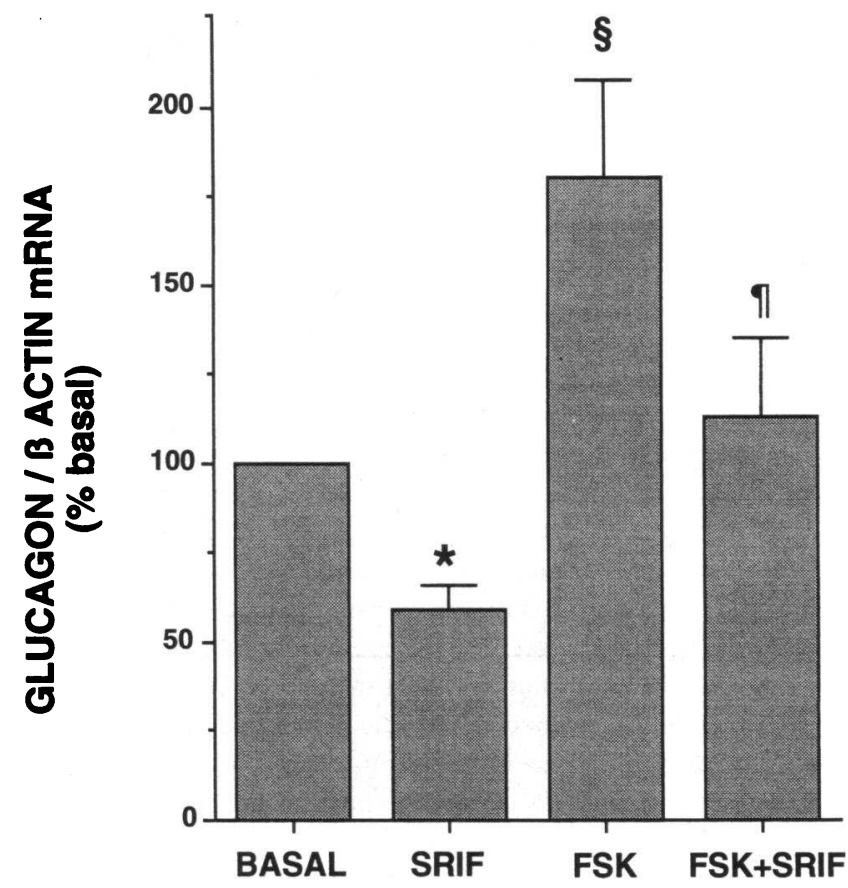

Figure 7. Quantitative densitometry of autoradiographs detecting glucagon mRNA in HIT-T15 cells. Replicate experiments $(n=4)$ demonstrate significant inhibition of glucagon mRNA level by SRIF in HITT15 cells. Exposure of HIT cells to SRIF significantly reduces both basal and FSK-stimulated mRNA levels. ${ }^{*} P<0.05$ versus basal, ${ }^{8} P$ $<0.02$ versus basal, ${ }^{\top} P<0.04$ versus FSK.

sensitive G-proteins and to examine whether SRIF may have previously unrecognized regulatory effects on glucagon gene expression. Confocal microscopy and immunohistochemical studies revealed that HIT-T15 cells contain insulin and glucagon and that these hormones tend to segregate into separate cells. As has been shown in pancreatic islets (19) significant inhibition of glucagon secretion by SRIF was observed in HIT cells. These studies uniquely demonstrate that SRIF-induced inhibition of glucagon secretion is dependent upon pertussis toxin-sensitive substrates. The current studies also demonstrate that SRIF reduces both basal and stimulated glucagon mRNA levels in HIT

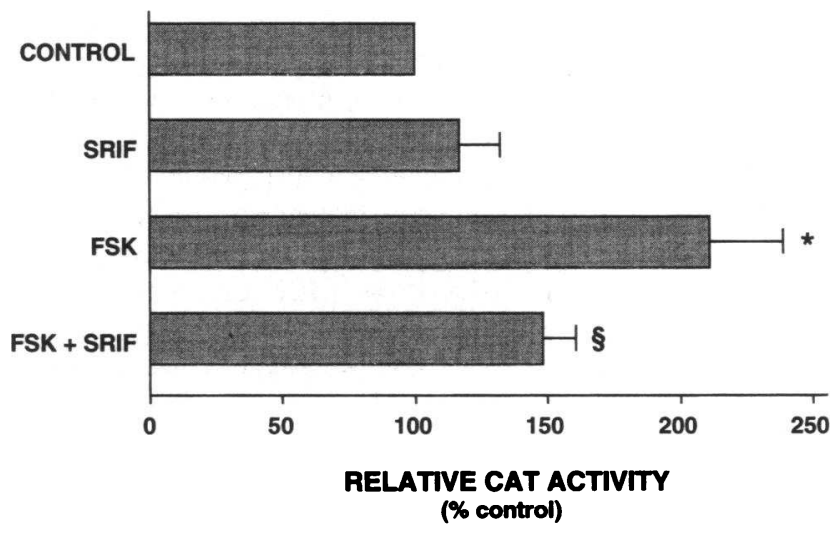

Figure 8. SRIF decreases rate of glucagon promoter activity in HITT15 cells. Relative glucagon-CAT activity in transient transfection experiments $(n=4)$. Exposure of HIT cells to FSK resulted in a twofold increase in promoter activity, and this increase was significantly inhibited by SRIF. ${ }^{*} P<0.01$ versus basal, ${ }^{8} P<0.05$ versus FSK. 
cells, an effect that was accompanied by parallel reductions in glucagon gene promoter activity. Our previous studies (20) established that HIT cells contain three specific $G_{i}$ alpha subunits $\left(G_{i 1}, G_{i 2}, G_{i 3}\right)$ and three forms of $G_{0}$, one or all of which may be necessary for mediating the inhibitory effects of SRIF.

This report demonstrates that SRIF can regulate pancreatic alpha cells at two levels, i.e., glucagon exocytosis and glucagon gene expression. Although this coordinate regulation of glucagon gene expression and hormone exocytosis by SRIF has not been reported previously, other islet hormones have been shown to regulate glucagon gene expression. For example, Philippe has reported that insulin inhibits both glucagon secretion and glucagon gene transcription in a hamster islet cell line $(4,21)$. Moreover, Drucker et al. (5) demonstrated that glucagon itself can feed back on the glucagon gene and negatively regulate its expression. In addition, it has been demonstrated that changes in cAMP can alter glucagon mRNA levels and glucagon promoter activity $(22,23)$, through a cAMP-responsive regulatory element previously identified within the 5 '-flanking region of the glucagon gene. More recently, glucagon gene expression in HIT cells has also been altered by inducing cell depolarization and calcium influx (9).

Although the present studies have not addressed the specific mechanisms by which SRIF inhibits glucagon gene expression, the work of others quoted above suggests that this effect may be mediated through the known glucagon promoter cAMP-responsive element $(22,23)$. SRIF-induced reductions in alpha cell adenylate cyclase activity would be anticipated to reduce cellular cAMP content, and this could directly reduce rates of glucagon gene transcription. In our studies, addition of exogenous cAMP analogue completely prevented the SRIF-induced reduction in mRNA, further supporting that cellular cAMP concentrations play an important role in mediating SRIF effects on the glucagon gene. On the other hand, it is also possible that SRIF-induced inhibition of cell depolarization or calcium influx (9), which themselves directly alter glucagon gene expression, could account for reductions in rates of glucagon gene transcription. That SRIF could induce posttranscriptional changes (such as decreased mRNA stability) remains a possibility even though we have demonstrated that decreased glucagon promoter activity in the HIT cell occurs in parallel with the reductions observed in mRNA levels. It seems unlikely that nonspecific effects on cell growth or total mRNA synthetic activity could be responsible for the changes we have observed because we normalized the Northern analysis data for total cellular mRNA content and levels of $\beta$-actin mRNA, and the transcription studies were normalized for nonspecific effects on a constitutive promoter of RSV.

In summary, we have uniquely demonstrated that SRIF regulates glucagon secretion in a pancreatic cell line through pertussis toxin-sensitive mechanisms that likely involve species of inhibitory G-proteins. In addition, SRIF also inhibits glucagon gene expression, at least in part by reducing rates of glucagon promoter activity. These findings suggest that SRIF can coordinately modulate glucagon delivery by the alpha cell both at the level of hormone synthesis and hormone secretion.

\section{Acknowledgments}

We are indebted to Hui-Jian Zhang for her assistance with Northern analysis and to Lawrence Stout for preparation of the confocal micro- scopic specimens. We also acknowledge Elizabeth Oseid and Laurie Pohlman for performing the glucagon radioimmunoassays and Jen Burkhart and Lucy Mittag for manuscript preparation.

\section{References}

1. Robertson, R. P., E. R. Seaquist, and T. F. Walseth. 1991. G proteins and modulation of insulin secretion. Diabetes. 40:1-6.

2. Zhang, H.-J., J. B. Redmon, J. M. Andresen, and R. P. Robertson. 1991 Somatostatin and epinephrine decrease insulin messenger ribonucleic acid in HIT cells through a pertussis toxin-sensitive mechanism. Endocrinology. 129:24092414.

3. Redmon, J. B., H. C. Towle, and R. P. Robertson. 1994. Regulation of human insulin gene transcription by glucose, epinephrine, and somatostatin. Diabetes. 43:546-551.

4. Philippe, J. 1989. Glucagon gene transcription is negatively regulated by insulin in a hamster cell line. J. Clin. Invest. 84:672-677.

5. Drucker, D. J., Y. C. Lee, S. L. Asa, and P. L. Brubaker. 1992. Inhibition of pancreatic glucagon gene expression in mice bearing a subcutaneous glucagonproducing GLUTag transplantable tumor. Mol. Endocrinol. 6:2175-2184.

6. Santerre, R. F., R. A. Cook, R. Crisel, J. D. Sher, R. J. Schmidt, D. C. Williams, and C. P. Wilson. 1981. Insulin synthesis in a cloned cell line of simian virus 40 transformed hamster pancreatic $\beta$ cells. Proc. Natl. Acad. Sci. USA. 78:4339-4343

7. Seaquist, E. R., A. R. Neal, K. D. Shoger, T. F. Walseth, and R. P. Robertson. 1992. G-proteins and hormonal inhibition of insulin secretion from HIT-T 15 cells and isolated rat islets. Diabetes. 41:1390-1399.

8. Diem, P., T. F. Walseth, H.-J. Zhang, and R. P. Robertson. 1990. Secretion and degradation of glucagon by HIT cells. Endocrinology. 127:1609-1612.

9. Schwaninger, M., G. Lux, R. Blume, E. Oetjen, H. Hidaka, and W. Knepel 1993. Membrane depolarization and calcium influx induce glucagon gene transcription in pancreatic islet cells through cyclic AMP-responsive element. J. Biol. Chem. 268:5168-5177.

10. Olson, L. K., J. B. Redmon, H. C. Towle, and R. P. Robertson. 1994. Chronic exposure of HIT cells to high glucose concentrations paradoxically decreases insulin gene transcription and alters binding of insulin gene regulatory protein. J. Clin. Invest. 92:514-519.

11. Harris, V., G. R. Faloona, and R. H. Unger. 1979. Glucagon. In Methods of Hormone Radioimmunoassay. B. M. Jaffe and H. R. Behrman, editors. Academic Press, New York. 643-656.

12. Brelje, T. C., D. W. Scharp, and R. L. Sorenson. 1989. Three-dimensional imaging of intact, isolated islets of Langerhans using confocal microscopy. Diabetes. 38:808-814.

13. Brelje, T. C., M. W. Wessendorf, and R. L. Sorenson. 1993. Multi-cblor laser scanning confocal immunofluorescence microscopy: practical application and limitations. In Cell Biological Applications of Confocal Microscopy. Methods in Cell Biology. B. Matsumoto, editor. Academic Press, San Diego, CA. 38:98193.

14. Ronner, P., F. Matschinsky, T. L. Hang, A. J. Epstein, and C. Buettger. 1993. Sulfonylurea-binding sites and ATP-sensitive $\mathrm{K}^{+}$channels in $\alpha$-TC glucagonoma and $\beta$-TC insulinoma cells. Diabetes. 42:1760-1772.

15. Zhang, H.-J., T. F. Walseth, and R. P. Robertson. 1989. Insulin secretion and cAMP metabolism in HIT cells. Reciprocal and serial passage-dependent relationships. Diabetes. 38:44-48.

16. Chomczynski, P., and N. Sacchi. 1987. Single step method of RNA isolation by acid guanidinium thiocyanate-phenol-chloroform extraction. Anal. Biochem. 162:156-159.

17. Drucker, D. J., R. Campos, R. Reynolds, K. Stobie, and P. L. Brubaker. 1991. The rat glucagon gene is regulated by a protein kinase A-dependent pathway in pancreatic islet cells. Endocrinology. 128:394-400.

18. Lowry, O. H., N. J. Rosesbrough, A. L. Farr, and R. J. Randall. 1951. Protein measurement with the Folin phenol reagent. J. Biol. Chem. 193:265-275.

19. Koerker, D. J., W. Ruch, E Chideckel, J. Palmer, C. J. Goodner, J. Ensinck, and C. C. Gale. 1974. Somatostatin: hypothalamic inhibitor of the endocrine pancreas. Science (Wash. DC). 184:482-484.

20. Seaquist, E. R., A. R. Neal, K. D. Shoger, T. F. Walseth, and 'R. P. Robertson. 1992. G-proteins and hormonal inhibition of insulin secretion from HIT-T15 cells and isolated rat islets. Diabetes. 41:1390-1399.

21. Philippe, J. 1991. Insulin regulation of the glucagon gene is mediated by an insulin responsive DNA element. Proc. Natl. Acad. Sci. USA. 88:7224-7227.

22. Knepel, W., J. Chafitz, and J. F. Habener. 1990. Transcriptional activation of the rat glucagon gene by the cyclic AMP-responsive element in pancreatic islet cells. Mol. Cell. Biol. 10:6799-6804.

23. Philippe, J., D. J. Drucker, W. Kneppel, L. Japeal, and J. F. Habener. 1988. Alpha-cell-specific expression of the glucagon gene is conferred to the glucagon promoter element by the interactions of DNA-binding proteins. Mol. Cell. Biol. 8:4877-4888. 